\title{
The Influence of Teacher Librarians' Personal Attributes and Relationships with the School Community in Developing a School Library Programme
}

\author{
Marisa McPherson \\ Victoria University of Wellington, New Zealand
}

\begin{abstract}
The ability of teacher librarians worldwide to develop and maintain school library programmes has been severely constrained by a number of factors ranging from inadequate budgetary allocations, lack of support from principals and other key stakeholders such as Ministry of Education personnel. However, even with limited funding and support, some teacher librarians have used ingenious strategies to develop and maintain their library programmes. This literature review synthesizes international research obtained from peer-reviewed journals, theses and professional papers on the personal attributes that a teacher librarian should possess in order to influence the development of a school library programme and the types of relationships the teacher librarian need to have with key stakeholders to be successful. The literature examined spanned a time period mostly from 2000-2018. The literature review found that leadership, collaboration, communication and interpersonal skills were the dominant skills a teacher librarian should possess in order to develop and maintain a school library programme alongside a good relationship with the school community.
\end{abstract}

\section{Introduction}

The library is the heart of the school for both teachers and students (Lindsay, 2006; Mokhtar \& Majid, 2005). School libraries contribute not only to the academic achievement of the students, but also to the development of other lifelong skills such as self-confidence, interpersonal skills, critical thinking, problem-solving, positive self-perception, and building responsible citizens who can function effectively in society (Baker, 2016; Barrett, 2010; Lance, Rodney \& Russell, 2007; McCracken, 2001; Mokhtar \& Majid, 2005; Stewart, 2014; Wittie, Gross \& Latham, 2014/2015). Many empirical studies relate the school library to students' academic success, development of life-long skills and nation building (Abdulsalami, Okezie, \& Agbo, 2013; Juchnevic, 2014; Omeluzor, Bamidele, Ukangwa \& Amadi, 2013), school libraries appear to be undervalued and teacher librarians have to demonstrate their worth to principals and the wider school community in order to receive support. In addition, school libraries are often among the first areas in schools to lose support when principals and other administrators are faced with decisions about where to invest their shrinking budgets (Massey, DiScala, Weeks, Barlow, \& Kodama, 2016; Mokhtar \& Majid, 2005). This situation has resulted in reduced access to information resources and services for students who have few options beyond the school library. The attendant result is a negative impact on students' academic achievement and students falling behind in learning the information

\footnotetext{
Copyright of works published in School Libraries Worldwide is jointly held by the author(s) and by the International Association of School Librarianship. The author(s) retain copyright of their works, but give permission to the International Association of School Librarianship to reprint their works in collections or other such documents published by or on behalf of the International

Association of School Librarianship. Author(s) who give permission for their works to be reprinted elsewhere should inform the Editor of School Libraries Worldwide and should ensure that the following appears with the article: Reprinted, with permission, from School Libraries Worldwide, Volume 26, Number 1, January 2020 pages 136-150. doi: 10.14265.26.1.02
} 
literacy skills necessary for success in an information economy (Lindsay, 2006; Massey, DiScala, Weeks, Barlow, \& Kodama, 2016; Strong, 2014).

The American Library Association (ALA) (2012), the oldest and largest library association in the world, has stated that to have a strong school library programme, the library must be staffed with a certified librarian who collaborates with all school professionals. The International Federation of Library Associations and Institutions (IFLA), added to the discussion by mentioning that:

The richness and quality of a school library programme primarily depends upon the human resources available within and beyond a school library. To meet the teaching and learning needs of a school community, it is essential to have a well-trained and highly motivated staff, in sufficient numbers according to the size of the school and its unique need (p. 25).

This view has been underscored by many other authors who have mentioned that the school library can have a greater impact when it is staffed with a qualified teacher-librarian who is able to develop the collection to suit curriculum needs, foster effective use of the resources to support learning and improve the information literacy skills of both teachers and students (Barrett, 2010; Hughes, 2014; Lindsay, 2006; McCracken, 2001; Mokhtar \& Majid, 2005).

To remain viable, teacher librarians have found ingenious ways to sustain their programmes. Strategies used by teacher librarians involve drawing on certain individual attributes and establishing a good working relationship with the school community. Greenwood, Creaser and Maynard (2008) conducted a survey of six primary schools to identify the factors that contribute to their successful libraries given their funding, staffing and accommodation constraints. All the schools except one faced considerable financial limitations and the teacher librarian or person in charge of the libraries had to be creative and ingenious to overcome the obstacles. Among the strategies employed were to use students and parents as library helpers to make up for the lack of adequate staff, soliciting help from the parent-teacher association (PTA) for assistance with fundraising activities, cataloguing of book etc., and maintaining a close relationship with the public library for support in developing the school library. The librarians' successes were also attributed to certain personal attributes as reported by other staff members when interviewed, including their strong leadership, commitment, enthusiasm, dedication in making the library a success, passion about books and the library, and innovativeness which were considered 'critical' to the success of the library. Some librarians were deemed to be visionaries who were instrumental in driving the development of the library forward. Some were also described as flexible, helpful and polite.

The potential impact of a combination of teacher librarian personal attributes and relationships with the school community are important to compile and review because even when support from the school community is lacking, teacher librarians who have certain personal attributes and relationships may be able to develop library programmes.

\section{Literature Review Method}

This literature review brings together what little has been written on the personal attributes that are required by teacher librarians and the relationship that needs to exist between them and key stakeholders in order for the development and maintenance of a school library programme. Given the dearth of information in the library and information science domain, information was also drawn from other areas such as accounting and business. The literature review will first discuss the main personal attributes that a teacher librarian should possess; the relationships that the 
teacher librarian must form within the school community; classroom teacher and principal perceptions of the library; and the benefits of these relationships.

The articles cited in this article were gathered from mostly peer-reviewed journal articles, $\mathrm{PhD}$ theses and professional papers obtained predominantly from EBSCOHost suite of databases. Keyword searches included but were not limited to, 'personal attributes', 'teacher librarian', 'school librarian', 'school library', 'school community', 'leadership', 'collaboration', 'communication', 'interpersonal skills', 'school environment,' 'teachers', 'principals,' 'teachers perception of school library,' 'principal perception of school library.' Majority of the articles were published between 2000-2018 with a few published in the late 1990's. These articles were included because their information was very relevant to the topic.

Selected journals included but were not limited to School Libraries Worldwide, School Library Media Research, School Library Journal, Journal of Academic Librarianship, Journal of Library and Information Management, International Journal of Library and Information Science, Library Trends, Journal of Education for Library and Information Science. The reference lists of all publications identified were examined to retrieve other potentially relevant publications not identified by the computerized search. Articles found in the initial search were selected based on occurrence of search terms found in the title and keywords in the abstract. Articles were then skimmed to determine relevancy then assigned categories as they emerged for manageability of the large number of articles collected. Following this, the articles were reviewed for consistent mention of the key attributes which were recorded and the top four were selected.

\section{Key Personal Attributes}

\section{Definition of Personal Attributes}

Personal attributes are not clearly defined in the library and information science (LIS) literature. Most authors have listed and discussed personal attributes required by individuals to be successful or get a job, but Dawson, Abbott and Shoemaker (2011), provided a succinct definition of personal attributes as "one's values and characteristics" (p.292). Zagorsek, Svetina and Jaklic (2008) reinforced this definition by defining personal attributes as "traits, skills and behaviours" (p. 100). LIS literature has included numerous personal attributes required by leaders in librarianship and other disciplines to be successful or to find a job. However, the four most frequently discussed personal attributes discussed in the literature are leadership skills, communication skills, collaborative skills and interpersonal skills. Figure 1 summarises these attributes.

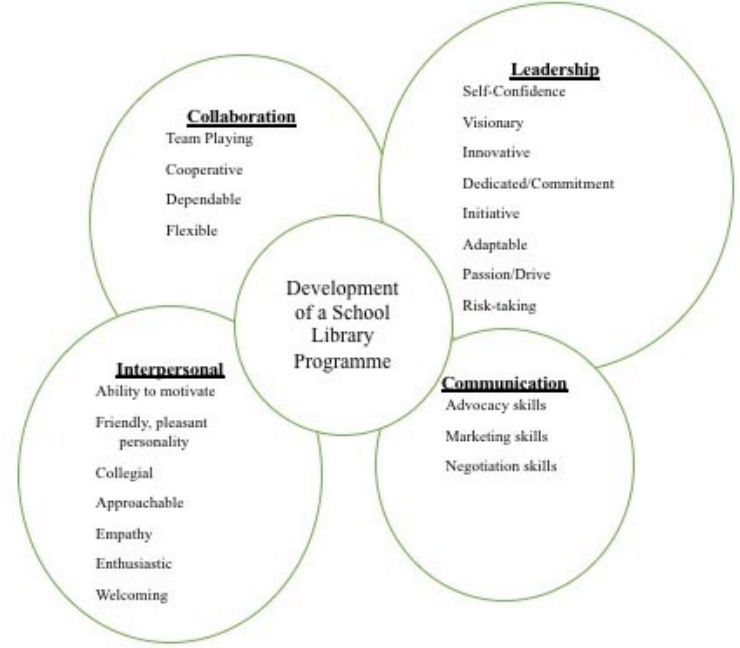

Figure 1. Personal attributes required for school library programme development. 


\section{Leadership}

Leadership was the most frequently discussed personal attribute in the literature and is essential for school librarians. Zagorsek, Svetina and Jaklic (2008) defined leadership as the "ability of an individual to influence, motivate and enable others to contribute towards the effectiveness and success of the organizations of which they are members," (p. 101). Possessing leadership skills according to Patridge, Menzies, Lee and Munro (2010) also involves the "ability to influence people, negotiate and encourage staff and clients to move to new horizons" (p. 270), including taking initiative and making things happen through the effective action of others (Young, Powell \& Hernon, 2006). A teacher librarian need to be a leader to develop a school library programme, ensure visibility in the school, and show the wider school community the importance of the library to the school by building awareness in the school community of the teacher librarian's role and the benefits of the school library. Baker (2016) mentioned that accomplished school librarians are leaders in their profession, in the administration of their libraries, instructional leaders who provide learning opportunities for teachers and students and technology integration leaders.

Authors such as Baker (2016), Clephane (2014), Church (2011) and Johnston (2012a) have identified the need for teacher librarians worldwide to assume more leadership roles in this technological era. To assume the position of technology leaders in schools, it is imperative that the teacher librarian works closely with both classroom teachers and students to integrate technology in the teaching-learning process and teach information literacy. According to Baker (2016) this role of the teacher librarian is very important because students need to have skills in multiple literacies so that they acquire the skills and knowledge to succeed in this ever-changing technological society. Some studies have shown that teacher-librarians are poised to take on this role (BranchMueller \& DeGroot 2011; Johnston, 2012b). For example, Johnston (2012b) examined school librarians as technology integration leaders, noting that teacher-librarians are uniquely positioned to undertake the role of technology leadership because of their 'knowledge of pedagogical principles and curriculum, paired with technology and information expertise,' (p.15). This unique skill set has made teacher-librarians indispensable to lead the charge of technology integration in schools.

The literature, however, also points to several contextual factors that have been inhibiting the teacher librarian from assuming such a critical role. These factors include uncollaborative and unsupportive staff, insufficient quantity of resources, insufficient staffing of the libraries, low perception of many school librarians in the organizational structure of the school, obsolete equipment, lack of time to work with teachers including planning and learning about the technologies among others (Calvert, 2016; Johnston, 2012b). For the teacher librarian to overcome some of these barriers he or she will require strong leadership skills which will involve being innovative and adaptive.

The American Association of School Librarians (ASSL) (2015) toolkit for promoting school library programmes articulates some of the key roles that a teacher librarian should play to be a leader in the school. These duties include attending grade-level or department meetings monthly, becoming a first responder to technology questions, leading professional development in technology for teachers and other staff, sharing examples of the programme's direct impact on student achievement, developing goals and action plans for the school library programme and communicating them to the principal and teachers among others. Similarly, Blair (1978) and Lindsay (2006) propose that the teacher librarian should look for opportunities to serve on committees, and volunteer to assist with curriculum planning so that the library's resources can be 
integrated which will also foster a working relationship with the teachers who will naturally want to collaborate with the teacher librarians on those units.

Employers are keen on recruiting persons who possess leadership skills and oftentimes these requirements are stated in job advertisements. Many studies have articulated the need of prospective employers to require professional staff to possess leadership skills; for example, the Australian neXus2 research project which surveyed LIS professional employers, identified the required knowledge, skills and attributes required by employers and $75 \%$ of the respondents noted leadership skills (Hallam, 2009). Reeves and Hahn (2010) also found that employers who were looking to hire staff wanted persons who possess leadership skills, are adaptable, innovative and initiative. Young, Hernon and Powell (2006) compared the attributes (including managerial and personal attributes along with the area of knowledge) most valued by Gen-Xers (i.e., people born between 1965 and 1979) and those most valued by library directors, the ability to serve as an advocate was ranked in the first quartile of the results by the academic directors. In a similar study conducted by the same authors in 2003 using the Delphi technique, the results indicate that 'vision' got very high marks.

Several researchers (e.g., Lance, Hamilton-Pennell \& Rodney, 2000; Todd \& Kuhlthau, 2005), have attributed increased student learning to an active teacher librarian leader, which underscored Church's (2011) comment that "not to take advantage of this highly qualified instructional staff member is to fail to utilize human resources to the fullest" (p. 12).

\section{Collaboration}

The ability to collaborate is another of the key attributes needed for a teacher librarian to develop and grow a school library programme. Collaboration is defined by Montiel-Overall (2008) as a "trusting, working relationship between two or more equal participants involved in shared thinking, shared planning and shared creation of integrated instruction" (p.150). No teacher librarian can develop and grow a library programme without collaboration with administrators and teachers because it is through this collaborative effort that the teacher librarian will be able to integrate the library into the teaching-learning process. Collaboration is essential as teacherlibrarians work with teachers to plan, conduct and evaluate learning activities that incorporate information literacy. As the catalyst for collaboration, it is imperative that the teacher librarian initiates collaborative efforts that are focused on meeting the learning needs of students both within and beyond the school library (AASL, 2018).

Partidge, Lee and Munro (2010) conducted a series of focus groups among Australian LIS professional on the key skills, knowledge and attributes required by librarian 2.0 and the results revealed that all focus groups identified collaboration and teamwork as being a core requirement for the 2.0 librarian. The authors revealed that librarian 2.0 need to be able to work successfully as part of a team and across disciplines. This person must also be able to build and establish relationships and partnerships and establish networks, with individuals and groups wherever it is needed. Reeves and Hahn (2010), conducted similar studies and found that prospective employers were looking for persons who possess the ability to collaborate and cooperate with people. Similarly, Young, Hernon and Powell (2006) found that the ability of prospective staff to work collaboratively with campus colleagues was ranked highly by academic library directors.

\section{Communication}

Being able to communicate verbally and in writing was another popular attribute found in the literature. Communication refers to the sharing of meaning and timely information using informal and formal means (Heffernayn \& Sweeney, 2009). The teacher librarian must interact with both 
internal and external stakeholders to develop and grow a school library programme and therefore must be able to communicate effectively. Several studies have highlighted the need for effective communication between teacher librarian and administrator to get financial support for the school library programme. The frequency of communication between school principals and school library media specialists concerning budget has been shown to correlate with the level of financing allocated for library media materials (Chow \& Rich, 2012; Shannon, 2002; Zagorsek, Svetina \& Jaklic, 2008). Ash-Argyle and Shoman (2012) contended that high-quality, effective communication between teacher librarian, principal and teachers is one of the most influential factors on the librarian's success at work. Good communication skills are of paramount importance if the teacher librarian hopes to get the support from the school community because the teacher librarian must be able to communicate the mission, goals, objectives, accomplishment and contributions of the programmes to make the library media centre an integral part of the total school programme. It is also important for the teacher librarian to strengthen his/her lines of communication with the students to be able to influence them to use the library, (AASL, 2015). This communication could involve presentation at devotions, general assemblies, the establishment of a monthly newsletter, etc.

Partridge, Lee and Munro (2010) and Storey (2009) argued that a school librarian must know how to be an advocate and lobbyist for the resources and programmes he or she wants to introduce, especially when faced with competing agendas or policies of the information technology department and senior management. In such instances, librarians need to be able to exhibit good negotiating and diplomacy skills as well be able to use appropriate language for persuading or influencing the target audience to their point of view. Librarians should possess marketing and promotion skills so that they are able to sell their skills and knowledge to stakeholders. Excellent presentation skills are also essential. Likewise, a teacher librarian must be able to run meetings effectively, present ideas clearly and enthusiastically both orally and in writing.

Tempone, Kavanagh, Segal, Hancock, Howieson, and Kent (2012) mentioned that desirable generic attributes for accounting graduates in the twenty-first century revealed that good communication skills are important. Even though their study focused on accountancy, the same principle can be applied to the field of librarianship. The authors mentioned that the accountant 'needs to have good oral speaking skills to be able to stand up and deliver a presentation to a group of individuals, hold their own in boardroom negotiations and discussions' (p. 48-49). Similarly, these skills are extremely useful for teacher librarians to enable them to make more persuasive and convincing cases to obtain the support of the chairman, principal, and teachers for the school library programme considering the competing demands for the scarce resources of the school.

Communication skills rank highly among the personal attributes that employers seek (Hallam, 2009). Haddow's (2012) examination of the most important knowledge, skills and attributes that are required of reference librarians in Australia revealed that good communications skills were regarded as some of the most important attributes for academic reference librarians today. Similarly, Young, Hernon and Powell (2006), found that in regard to prospective professional staff, excellent oral and written communication skills were reported as highly desirable by the academic library directors. The same authors in 2003 conducted a similar study which showed that communication skills as a personal attribute got very high marks from library directors because being able to articulate/communicate the vital role of the library to the community was important. 
Partidge, Lee and Munro (2010) conducted a series of focus groups among Australian LIS professionals on the key skills, knowledge and attributes required by librarian 2.0 and the results revealed that all focus groups identified communication as being a core requirement. The authors revealed that communication skills go beyond possessing mere written and oral skills because a contemporary teacher librarian must know how to advocate and lobby for the resources and programmes, especially when faced with competing agendas or policies. The ability to communicate orally and in writing is a key personal attribute needed by teacher librarians, especially given the harsh economic crisis in which principals must prioritise given their shrinking budget. The teacher librarian who possesses strong communication skills will have to be able to lobby aggressively and negotiate for some of the scarce resources.

\section{Interpersonal Skills}

A teacher librarian's role involves working with people, therefore interpersonal skills feature heavily in the literature as a personal attribute needed for a teacher librarian to be able to develop and grow a library programme. Interpersonal skills are primarily the ability to communicate or interact well with other people. Working with people and forming good relationships are important for the teacher librarian, therefore he/she must possess strong interpersonal skills as teacher librarians are expected to relate well to the principal, teachers, students and the wider school community. This has been supported in the literature by Lupton (2016) whose study looked at principal's perceptions of the role of the teacher-librarian. The principals were asked to describe the qualities they would look for if they were to recruit a new teacher-librarian and the responses included interpersonal skills such as being collegial and a 'people person.' Library leaders must be able to work with all kinds of people and reflect a "helpful and outgoing personality" and the ability to consider the thoughts and inputs of others [which] has a calming effect that allows them to set a positive direction and balance compassion and firmness" (Chow and Rich, 2013, p. 8).

\section{Relationship with the School Community}

In 2018, AASL published a blueprint formula for an effective school library programme and what the teacher librarian must do. However, this document did not acknowledge or address contextual issues or explore if and how factors external to the library will affect the implementation of a viable programme. It is therefore important to consider contextual issues because the teacher librarian's relationship with the school community will have a direct impact on what the teacher librarian would be able to accomplish. This is important because it acknowledges that context is a key dimension in school library activities and points specifically to the fact that teacher librarians are keenly aware of the fact that the relationship with the school community is an important element of that context.

Klinger, Lee, Stephenson and Lau (2009) lend their support to this view by mentioning that the development of a school library programme is a complex process, influenced by many contextual factors. For example, researchers in Ontario, Canada, identified contextual factors in the development of exemplary school libraries, including: "school level board policies; school board level support; funding models; staffing models; administrative support; demographics; principal knowledge; teacher knowledge; teacher librarian experience; teacher librarian skills, physical features of the library, history of the library and community and parent involvement" (p.18).

The school community consists of several actors; however, this paper will only review the principal and the teachers because these two actors are key in providing context as to how the teacher librarian will be able to develop and grow a school library programme. There are various studies that focus on the teacher librarian as an integral part of the school, but they do not examine 
the relationship with the school community or the influences the existing relationship may have on implementing a school library programme (Howard, 2010).

\section{Teacher Librarian Relationship with Principal}

Librarianship requires people working together to achieve a common goal (Oberg, 2009a). A teacher librarian must develop a relationship with different stakeholders (e.g., the principal, teachers, students) to develop and sustain a school library programme. Building these relationships requires time and energy, as well as mutual understanding. Church (2008), noted that the teacher librarian working with school and community partners results in an expansion and improvement of resources and services for all students.

The library and information science literature is inundated with studies that link the support of the principal to the development of a school library programme (Ash-Aryle \& Shoman, 2012; Hartzell, 2000b; Henri \& Boyd, 2002; Oberg, 1995; Shannon, 2009; Todd \& Kuhlthau 2005). Hartzell (2000b), who has researched and written extensively on the matter, asserts that for a school librarian your 'principal relationship at work is your relationship with the principal. You may be the best school librarian to ever grace education, but you won't get the opportunity to prove that unless your principal values what you do,' (p. 46). While I am in total agreement with the first half of the statement, I disagree with the second half. It may be a herculean task for the school librarian to prove that he/she is the best without the principal valuing what he/she does, but it can be done if the teacher librarian possesses certain personal attributes and ingenuity. It may not happen immediately and will certainly require a lot of effort but if the teacher librarian is passionate, relentless and ingenious he/she will be able to develop, grow and sustain a school library programme.

The support of the principal is also linked to the principal's perception and value of the school library. This has been supported by numerous studies that have drawn a correlation between the principals' perceptions of the library and their lack of support for the school library programme (Hartzell, 2003; Lau, 2002; Oberg, 1997). Authors have postulated that a principal's past experiences with a library shape their view on the importance of a library to a school (Radebe, 1997). This perception is oftentimes linked to their understanding of the function of a school library and its value to the school. As Linderman (1944), one of the first to have written on this topic pointed out:

A library-minded principal, one whose interest goes far beyond the fulfilment of prescribed standards, who sees the need for library service closely integrated with the entire teaching programme, will stimulate both the library and teaching staffs to make the library an important factor in education (p.611).

Many issues facing school libraries is as a result of the fact that some principals do not understand the teacher librarian's role (e.g., Church, 2008) and think that the teacher librarian should be playing the role of a teacher more than a librarian as they can employ any library assistant to deal with library administration (Lupton, 2016). In a study of principals' perceptions of the role of the teacher-librarian in Australia, Lupton (2016), found that principal's views varied on the role of the teacher librarian based on personality and expertise of the individual teacher librarian. Several of the principals thought the teacher librarian's primary role is that of a teacher and the funding that they have is needed for teaching as once again they feel that they can hire a library assistant to maintain library functionality. There was even one principal who had already replaced his teacher librarian with a lower-paid library assistant. There are however some principals who are very supportive of their teacher librarians as reported by Church (2008), 
LaRocque and Oberg (1990), and Oberg (1997). They contend that principals supported their teacher librarians by meeting with them regularly, ensuring that they serve on major school committees, and encouraging teachers to work with them; those studied principals ensured that teacher-librarians had flexible scheduling to work with teachers, provided clerical staff, and hired substitute teachers to release teachers and teacher librarians for major planning efforts. The principals facilitated staff awareness through teacher librarian meeting presentations, staff orientation and in-service sessions, and brief, frequent casual hallway or staffroom encounters to alert teachers to the benefits of the school library programme. These principals also checked to see if teachers had worked with the teacher librarians and informally encouraged teachers to work with the teacher librarian. In short, these principals modelled the commitment they expected of teachers and they integrated the school library programme into the general programme of the school.

Many researchers have addressed the importance of the principal to the development of the school library. Todd and Kuhlthau (2005) posited that support of the school principal and teaching faculty is an essential factor for effective school library programmes. Asselin (2001) concurred that the principal plays a critical role to the development of effective school library programmes. Oberg (1995) stated that the principal's library support was vital to the whole educational system. Teacher librarians need the backing of their principal in order to effect change since the principal controls the budget and staffing allocation, school schedules and timetables as well as the composition of influential committees (Henri \& Boyd, 2002; Hartzell, 2000c; Lindsay, 2006). The principal has the most decisive impact on the library's role and the librarians' status and influences the frequency of library use since he/she has the power to encourage cooperation between teachers and librarians (Ash-Argyle \& Shoham, 2012). In addition, where the principal fosters teacher-librarian collaboration, the teachers are more likely to collaborate with librarians. This view was supported by Hartzell (2002), who stated that as important as money is, it's not the only measure of support. Equally important is the principal's role in creating a school environment where student library use and faculty/librarian's interaction are valued and promoted. For example, the librarian's opportunity to collaborate with teachers depends on the school schedule (which the principal controls) and how effectively principals encourage collaboration among teachers. When principals have a positive working relationship with teacher librarians, principals can serve as advocates and a source of support to promote school librarians as instructional partners. The quality of the relationship between the principal and the school librarian impacts the school library and the librarian's place within the school (Johnston, 2012b).

\section{Teacher Librarian Relationship with Classroom Teachers}

The AASL (2018) outlined several key responsibilities of the teacher librarian including leadership, technology integration and collaboration. A teacher librarian cannot be successful in a vacuum, therefore, he or she has to develop a good working relationship with the wider school community so that the school library can be integrated into the teaching-learning process. However, collaboration can be problematic because as per the definition, it involves working with people, which can be a difficult task (Lindsay, 2006). It depends on two or more individuals seeing a common goal through to completion which sometimes isn't easy because invariably people are different and have their own opinions. Despite the problems that can arise in collaboration, this is a very crucial role and the teacher librarians must work with teachers to plan, conduct and evaluate learning activities that infuse the library into the curriculum and incorporate information literacy. Blair (1978) put it succinctly by stating that the commandment for successful school librarianship must be: "Thou shalt work closely with thy teachers," (p.93). Blair (1978) further expounded on the commandment by articulating that the classroom teacher is the major factor 
affecting student's use of the library. The teacher's perceptions of the role and function of the centre determine how the students use the library. To gain greater integration of the library within the school's instructional programme requires increased understanding and acceptance by librarians, teachers and principals of the educational role of the school library.

A teacher librarian can never be successful without collaboration; therefore, the teacher librarian must find ways and means to work with those other people for the greater good of the school. Lee and Klinger (2011) and Witte, Gross, and Latham (2014/2015) indicated that collaboration is important for teachers and for the teacher librarian to develop a good relationships since teacher librarians augment classroom resources. Collaborative efforts allow the teacher librarian to become an agent of change.

\section{Classroom Teacher's Perception of the School Library}

Many LIS researchers pointed to challenges that teacher librarians experience because of classroom teachers' misguided and warped views regarding the school libraries and their benefits to the school population. Oberg (2009a) and Radebe (1997) found that ignorance and misperceptions about the role of the school library were a major cause of school library underutilization. Researchers attributed teachers' negative attitude to completing schooling without libraries, not utilizing the college library; libraries were peripheral to their learning and, subsequently, to their teaching. The teachers' lack of library use skills has been generally a major hindrance to the development of joint responsibility between themselves and teacher-librarians for individualized learning processes. Teachers' negative and apathetic attitudes were evidenced by viewing the library as a waste of time and staff not using the library; by very seldom sending students to the library except to get rid of them or when they are forced because of the existence of a library period; by visiting the library to watch private entertainment videos, by ridiculing the teacher librarian because of the perception that she or he had no work to do and in one case playing table tennis in the library.

\section{Mathematics and Science Teachers}

While some classroom teachers may welcome collaborative effort, others have been resistant. There are some specific subject areas in which teachers rarely collaborate with the teacher librarian. The literature shows that teachers of Mathematics and Science rarely collaborate with teacher librarians and are oblivious to the vast assistance that they can receive from the teacher librarians. Schultz-Jones and Ledbetter's (2009) assessment of science teachers' predisposition to collaborate with the teacher librarians found that science teachers did not know the extent to which the teacher librarian could assist them and their students in learning the processes of science although they demonstrated a degree of receptiveness. It is not always the teacher's fault; Mardis (2007) and Bader (2014) pointed out that teacher librarians often lack the personal content knowledge necessary to engage confidently with science educators. Similarly, Subramaniam and Edwards (2014) looked at the factors that shaped teacher-librarians' collaboration with mathematics teachers, and reported that teacher librarians stated that collaboration between teacher librarians and mathematics teachers did not naturally evolve because they perceived mathematics teaching and learning as "linear, isolated, and one in a corner somewhere (p. 193)." Bader's (2014) study also revealed that students' success in mathematics and science improve when the teacher librarian and the teachers of the subjects collaborate as teacher librarians are information specialists that have an advanced education to support instruction in all subject areas including science and mathematics. 


\section{Benefits of Teacher-Librarian Collaboration}

Collaborating with classroom teachers involves planning, designing, delivering and evaluating instruction. The teacher librarian will serve as a consultant; provide leadership, expertise and advocacy in the use of technology and resources, encourage students to accept responsibility for their own learning and manages personnel, resources, facilities and services that assist students to learn how to learn (Lindsay, 2006).

Teacher librarians collaborating with classroom teachers results in several benefits for the students, teachers, teacher-librarian and the entire school. Bilyeu (2009) and Montiel-Overall (2008), mentioned that collaboration between teacher librarians and classroom teachers results in increased student achievement and turns the teacher librarian into a valued partner in lesson design. This resulted in increased visibility for the teacher librarian as instructional leaders, in increased time for the teacher-librarian in curricular work, and increased promotion of their participation in the departmental professional communities. For example, Lance, HamiltonPennell and Rodney (2000) found that student scores improved when librarians cooperated with teachers in planning instruction, identifying materials, teaching information literacy skills and providing in-service training to teachers. Student's enthusiasm for going to the library and working in the library increased noticeably after teachers began collaborating with the librarian.

Researchers (Henri \& Boyd, 2001; Lau, 2002; Montiel-Overall \& Grimes, 2013; Ross and Kuhlthau, 2005) have suggested that some of the negativity and apathy towards the library by teachers is because of teacher librarians'. Paton-Ash and Wilmot (2015) stated that the school library will continue to be peripheral unless teachers see the school library and the teacher librarian as part of the teaching and learning programme and embedded in the curriculum. Library advocacy among teachers is necessary in order to change teachers' perception and practices. If teacher-librarians are going to get the recognition they truly deserve they need to start communicating their value.

\section{Conclusions and Implications}

Developing a school library programme requires the teacher librarian to have a good relationship with the school community and/or for the teacher librarian to possess empowering personal attributes ("values" and "characteristics"). This literature review has revealed the four prominent personal attributes that are required by leaders in the field of librarianship and other disciplines to be successful: leadership skills, communication skills, collaborative skills, and interpersonal skills. Teacher librarians also must maintain good relations with the principal and classroom teachers so that he/she can develop and sustain the school library programme.

This literature review has shown, first, how the personal attributes of a teacher librarian, and second, how his/her relationship with the principal and teachers can impact the development of a school library programme. However, while both factors have been shown in school library research to be important to the development of a school library programme, none of the previous studies have sought to combine them both in a single study. However, a synthesis of study findings suggests that teacher librarians need the right set of personal attributes and to maintain a good relationship with the school community to achieve success.

The old adage of "strength in numbers" is quite applicable, as the more support the teacher librarian is able to garner from the school community, the better the quality of the programme is likely to be. In addition, the right person with the requisite personal attributes along with the right support system in place working in harmony will result in stronger performance and greater impact and this can be applied not only in the field of Library and Information Studies but every other area. As schools continue to face financial constraints, teacher librarians will compete for 
scarce resources; therefore, it is important for teacher librarians to possess certain personal attributes and form a good relationship with the key stakeholders to develop, grow and maintain school library programmes. The environmental context has a significant role as it may directly impact the work of the teacher librarian by either supporting or hindering work. Without the support of the principal and teachers, teacher librarians can find themselves with severe constraints in delivering their work programmes.

\section{References}

Abdulsalami, L.T., Okezie, Q.I., \& Agbo, A.D. (2013). The role of the library in the promotion of knowledge societies in Nigeria. Advances in Applied Science Research, 4(1), 58-70. Retrieved from

http://www.imedpub.com/articles/the-role-of-the-library-in-the-promotion-of-knowledge-societiesin-nigeria.pdf

American Association of School Librarians (2018). AASL standard framework for learners. Chicago, IL: American Library Association.

American Association of School Librarians (2015). Toolkit messages, ideas and strategies for communicating the value of school library programmes and school librarians in the 21st century. Chicago, IL: American Library Association.

American Library Association. (2012). ALA resolution that school librarians are critical to educational success. Retrieved from http://www.aasl.ala.org/aaslblog/?p=2973

Anonymous. (1998). Competencies for teacher-librarians in the 21 ${ }^{\text {st }}$ century. Teacher Librarian, 26(2), 22-25.

Ash-Argyle, R \& Shoham, S. (2012). Librarians' leadership efficacy, training and school involvement: Collaboration between teachers and school librarians in Israel. School Libraries Worldwide, 18(1), 1-17.

Asselin, M. M. (2001). Factors of effective school libraries: a survey of perspectives of teachers, teacherlibrarians, and principals. In Hughes, P. \& Selby, I. Eds. Inspiring connections: learning, libraries \& literacy: proceedings of the Fifth International Forum on Research in School Librarianship. Seattle, Washington: IASL, 1-17.

Bader, J.E. (2014). Strengthening the connection between the school library and math and science. Master's thesis, University of Central Missouri, Missouri, USA.

Baker, S. (2016). From teacher to school librarian leader and instructional partner: A proposed transformation framework for educators of preservice school librarians. School Libraries Worldwide, 22(1), 143-159. doi: 10.14265.22.1.011

Barrett, L. (2010). Effective school libraries: Evidence of impact on student achievement. The School Librarian, 58(3), 136-139.

Blair, S. (1978). Teachers and the school resource centre. Canadian Library Journal, 35(2), 93-100.

Branch-Mueller, J., \& DeGroot, J. (2011). The power of web 2.0: Teacher-librarians become school technology leaders. School Libraries Worldwide, 17(2), 25-40.

Calvert, P. (2016). School libraries in New Zealand as technology hubs: Enablers and barriers to school librarians becoming technology leaders. School Libraries Worldwide, 22(2), 51-62.

Chow, A. S., \& Rich, M. (2013). The ideal qualities and tasks of library leaders: Perspectives of academic, public, school and special library administrators. Library Leadership and Management, 27(1/2), 1-25. Retrieved from https://libres.uncg.edu/ir/uncg/f/A_Chow_Ideal_2013.pdf

Church, A. P. (2008). The instructional role of the library media specialist as perceived by elementary school principals. American association of School Libraries, 11, 1-28. Retrieved from http://www.ala.org/aasl/sites/ala.org.aasl/files/content/aaslpubsandjournals/slr/vol11/SLMR_Instruct ionalRole_V11.pdf

Church, A. P. (2011). School librarians as teacher leaders. The Delta Kappa Gamma Bulletin, 77(3), 10-12. Retrieved from http://www.deltakappagamma.org/NH/DKGbulletinspring2011.PDF\#page=10

Clephane, S. (2014). New Zealand school librarians: Technology leaders? School Libraries Worldwide, 20(2), 1427. doi: 10.14265 .20 .2 .002 
Dawson, M, Abbott, J., \& Shoemaker, S. (2011). The hospitality culture scale: A measure organizational culture and personal attributes. International Journal of Hospitality Management, 30, 290-300. doi: 10.1016/j.ijhm.2010.10.002

Greenwood, H., Creaser, C., \& Maynard, S. (2008). Successful primary school libraries; case studies of good practices. Retrieved from http://www.lboro.ac.uk/microsites/infosci/lisu/downloads/successfulprim-sch-libs.pdf

Haddow, G. (2012). Knowledge, skills and attributes for academic reference librarians. Australian Academic and Research Libraries, 43(3), 231-248. doi: 10.1080/00048623.2012.10722279

Hallam, G. C. (2009). NeXus2: An investigation into the library and information services workforce in Australia. The institutional perspective: Final report. Retrieved from https://eprints.qut.edu.au/29051/

Hartzell, G. (2003). Why should principal's support school libraries? The Medium: Saskatoon, 42(3), 1-6. Retrieved from https://files.eric.ed.gov/fulltext/ED470034.pdf

Hartzell, G. (2002a). Principals of success: Getting the boss's attention is crucial to your effectiveness. School Library Journal, 48(4), 41.

Hartzell, G. (2002b). The principal's perceptions of school libraries and teacher-librarians. School Libraries Worldwide, 8(1), 92-110.

Hartzell, G. (2002c). Why should principal's support school libraries? https://files.eric.ed.gov/fulltext/ED470034.pdf

Heffernan, T., \& Sweeney, A. (2009). Personal attributes of effective lecturers: The importance of dynamism, communication, rapport and applied knowledge. International Journal of Management Education, 8(3), 13-27. doi: 10.3794/ijme.83.275

Henri, J., \& Boyd, S. (2001). Forging information literate school communities: A case study of teacher librarians' perceptions of their influence in the workplace. New Review of Children's Literature, 7(1), 93-103. doi: 10.1080/13614540109510646

Henri, J., \& Boyd, S. (2002). Teacher librarian influence: Principal and teacher librarian perspectives. School Libraries Worldwide, 8(2), 1-17.

Howard, J. K. (2008). The relationship between school culture and an effective school library program: Four case studies. Doctoral dissertation, Emporia University, Kansas, USA.

Hughes, H. (2014). School libraries, teacher-librarians and student outcomes: Presenting and using the evidence. School Libraries Worldwide, 20(1), 29-50. doi: 10.14265.20.1.004

Hughes, H., Hossein, B., Allan, C., \& Dicinoski, M. (2013). School libraries, teacher-librarians and their contribution to student literacy development in Gold Coast Schools. Research Report. Retrieved from https://eprints.qut.edu.au/60260/38/60260b.pdf

IFLA. (2015). School library guidelines, $2^{\text {nd }}$ edition. Retrieved from https://www.ifla.org/files/assets/schoollibraries-resource-centers/publications/ifla-school-library-guidelines.pdf

Juchnevic, L. (2014). Library roles in changing society. Social Transformations in Contemporary Society, 2, 120130.

Johnston, M.P. (2012a). Connecting teacher librarians for technology integration leadership. School Libraries Worldwide, 18(1), 18-33.

Johnston, M.P. (2012b). School librarians as technology integration leaders: Enablers and barriers to leaders to leadership enactment. School Library Research, 15. Retrieved from

http://www.ala.org/aasl/sites/ala.org.aasl/files/content/aaslpubsandjournals/slr/vol15/SLR_School_Li brarians_as_Technology_Integration_Leaders_V15.pdf

Kilinger, D.A., Lee, E.A., Stephenson, B., \& Luu, K. (2009). Exemplary school libraries in Ontario. Toronto, ON: Ontario Library Association. Retrieved from https://www.accessola.org/web/Documents/OLA/Divisions/OSLA/Exemplary-School-Libraries-inOntario.pdf

Lance, K.C., Hamilton-Pennell., C. \& Rodney, M.J. (2000). Measuring up to standards. The impact of school library programs and information literacy in Pennsylvania schools. Retrieved from ERIC database: http://eric.ed.gov/?id=ED446771

Lance, K.C., Rodney, M., \& Russell, B. (2007). How students, teachers and principals benefit from strong school libraries. The Indiana study 2007. Indianapolis. Retrieved from 
http://www.ala.org/tools/research/librariesmatter/how-students-teachers-principals-benefit-strongschool-libraries-indiana-study

LaRocque, L., \& Oberg, D. (1990). Building bridges between the library and the principal's office. Proceedings of the 19th Annual Conference of the International Association of School Librarianship, Umea, Sweden, 1-10.

Lau, D. (2002). What does your boss think about you? School Library Journal, 48(9), 52-55.

Lee, E.A., \& Klinger, D.A. (2011). Against the flow: A continuum for evaluating and revitalizing school libraries. School Libraries Worldwide, 17(1), 24-36.

Linderman, W. B. (1944). What should the school librarian expect of the school principal? The School Review, 52(10), 611-617. doi: 10.1086/441102

Lindsay, K. (2006). Teacher/teacher-librarian collaboration-A review of the literature. School Libraries in Canada, 25(2), 8-21.

Lupton, M. (2016). Adding value: Principal's perceptions of the role of the teacher-librarian. School Libraries Worldwide, 22(1), 49-61.

Mardis, M. (2007). School libraries and science achievement: A view from Michigan's middle schools. School Library Media Research, 10, 1-29. Retrieved from

http://www.ala.org/aasl/sites/ala.org.aasl/files/content/aaslpubsandjournals/slr/vol10/SLMR_School LibScienceAchievement_V10.pdf

Massey, S.A., DiScala, J., Weeks, A.C., Barlow, A.L., \& Kodama, C. (2016). The impact of the school district library supervisor: A review of the literature and an agenda for research and action. Library Quarterly: Information, Community, Policy, 86(4), 389-402. doi: 10.1086/688029

McCracken, A. (2001). School library media specialists' perceptions of practice and importance of roles described in information power. School Library Media Research, 4, 1-29. Retrieved from http://www.ala.org/aasl/sites/ala.org.aasl/files/content/aaslpubsandjournals/slr/vol4/SLMR_SLMSPe rceptions_V4.pdf

Mokhtar., I.A \& Majid, S. (2005). Use of school libraries by teachers in Singapore schools. Library Review, 54(2), 108-118. doi: 10.1108/00242530510583057

Monteil-Overall, P., \& Grimes, K. (2013). Teacher and librarians collaborating on inquiry-based science instruction: A longitudinal study. Library and Information Science Research, 35, 41-53. doi: 10.1016/j.lisr.2012.08.002

Montiel-Overall, P. (2008). Teacher and librarian collaboration: A qualitative study. Library and Information Science Research, 30, 145-155. doi: 10.1016/j.lisr.2007.06.008

Oberg, D. (1990). The school library programme and the culture of the school. Emergency Librarian, 18(1), 1-9.

Oberg, D. (1995). Principal support: What does it mean to teacher-librarians? In Sustaining the Vision: A selection of conference papers, 24th International Association of School Librarianship Conference, Worcester College of Higher Education, Worcester, England, July, 17-25. Retrieved from https://files.eric.ed.gov/fulltext/ED400851.pdf

Oberg, D. (1997). Principal support: Research from Canada. Retrieved from http://archive.ifla.org/IV/ifla63/63obed.htm

Oberg, D. (2009a). Changing school culture: The role of the $21^{\text {st }}$ century teacher-librarian. Retrieved from http://www.wasla.asn.au/wp-content/uploads/Changing-School-Culture-WA.pdf

Oberg, D. (2009b). Libraries in schools: Essential contexts for studying organizational change and culture. Library Trends, 58(1), 9-25. doi: 10.1353/lib.0.0072

Omeluzor,S.U., Bamidele, I.A., Ukangwa,C.C., \& Amadi, H.U. (2013). The relevance of a library in the 21st century: Students' perception. International Journal of Library and Information Science, 5(6), 160-166. doi: $10.5897 /$ IJLIS2013.0342

Patridge, H., Lee, J., \& Munro, C. (2010). Becoming a librarian 2.0: The skills, knowledge and attributes required by library and information science professionals in a web 2.0 world (and beyond). Library Trends, 59(1-2), 315-334.

Partridge, H. L., Menzies, V., Lee, J. M., \& Munro, C. (2010). The contemporary librarian: Skills, knowledge and attributes required in a world of emerging technologies. Library and Information Science Research, 32(4), 265-271. doi: 10.1016/j.lisr.2010.07.001 
Paton-Ash, M., \& Di Wilmot. (2015). Issues and challenges facing school libraries in selected primary schools in Gauteng province, South Africa. South African Journal of Education, 35(1), 1-10.

Radebe, T. (1997). Experiences for teacher-librarians in the workplace after completion of the school librarianship programme. South African Journal of Libraries and Information Science, 65(4), 218-226. doi: 10.7553/65-4-1462

Reeves, R.K., \& Hahn, T.B. (2010). Job advertisements for recent graduates: Advising, curriculum and jobseeking implications. Journal of Education for Library and Information Science, 51(2), 103-119.

Schultz-Jones, B.A., \& Ledbetter, C. (2009). Building relationships in the school social network: Science teachers and school library media specialists. School Libraries Worldwide, 15(2), $23-48$.

Shannon, D. (2002). The education and competencies of school library media specialists: A review of the literature. School Library Media Research, 5, 1-19. Retrieved from

http://www.ala.org/aasl/sites/ala.org.aasl/files/content/aaslpubsandjournals/slr/vol5/SLMR_Educatio nCompetencies_V5.pdf

Shannon, D.M. (2009). Principal's perspectives of school librarians. School Libraries Worldwide, 15(2), 1-22.

Simendinger, E., El-Kassar, A., Gonzalez-Perez, M.A., \& Crawford, J. (2017). Teaching effectiveness attributes in business schools. International Journal of Educational Management, 31(6), 780-800. doi: 10.1108/IJEM-05-2016-0108

Stewart, P.L. (2004). Jamaican school libraries empowering students with life skills: A survey. Journal of Library and Information Science, 2(1), 5-21.

Storey, C. (2009). Librarian interrupted! Ur-librarian to an un-librarian, or ur-librarian to uber-librarian? Library Management, 30(4/5), 276-285. doi: 10.1108/01435120910957931

Strong, C. (2013). The importance of school library programmes for increased academic achievement and sustainable education in the United States. Educational Research Journal, 28(1-2), 85-102.

Subramaniam, M., \& Edwards, A R. (2014). The collaboration conundrum between school librarians and mathematics teachers. De Gruyter. 64(2), 185-209. doi: 10.1515/libri-2014-0015

Tempone, I., Kavanagh, M., Segal, N., Hancock, P., Howieson, B., \& Kent, J. (2012). Desirable generic attributes for accounting graduates into the twenty-first century: The views of employers. Accounting Research Journal, 25(91), 41-55. doi: 10.1108/10309611211244519

Todd, R \& Kuhlthau, C. (2005. Student learning through Ohio school libraries, Part 1: How effective school libraries help students. School Libraries Worldwide, 11(1), 63-88.

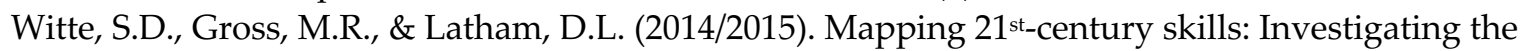
curriculum preparing teachers and librarians. Education for Information, 31, 209-225. doi: 10.3233/EFI150957

Young, A., Hernon, P., \& Powell, R.R. (2006). Attributes of academic library leadership: An exploratory study of some gen-xers. The Journal of Academic Librarianship, 32(5), 489-502.

Young, A., Powell, R.R., \& Hernon, P. (2003). Attributes for the next generation of library directors. Retrieved from http://www.ala.org/acrl/sites/ala.org.acrl/files/content/conferences/pdf/hernon.pdf

Zagorsek, H., Svetina, A.C., \& Jaklic, M. (2008). Leadership in clusters: Attributes of effective cluster leader in Slovenia. Transformations in Business \& Economics, 7(2), 98-113.

\section{Author Note}

Marisa McPherson is a doctoral candidate at the Victoria University of Wellington in New Zealand. Marisa worked as a teacher librarian before becoming an academic librarian at the University of the West Indies in Mona, Jamaica. Her research interest includes school libraries, library anxiety, information literacy, and school-family and community involvement. 
Reproduced with permission of copyright owner. Further reproduction prohibited without permission. 